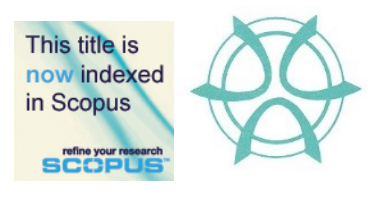

PLANNING MALAYSIA:

Journal of the Malaysian Institute of Planners

VOLUME 18 ISSUE 3 (2020), Page 326 - 337

\title{
THE ATTRIBUTES OF FUTURE SOCIAL LEARNING BUILT ENVIRONMENTS TOWARDS 21st CENTURY EDUCATION IN TERTIARY EDUCATION
}

\author{
V. Ramu ${ }^{1}$, Nooriati Taib ${ }^{2}$, Nor Fadzila Aziz \\ ${ }^{1,2,3}$ School of Housing, Building and Planning \\ UNIVERSITI SAINS MALAYSIA
}

\begin{abstract}
In the past two decades, the transformation that has captured tertiary education worldwide is a significant task mentioned as "academic evolution". Whereby, the vast exploitation of Information and Communication Technology (ICT) explicitly mentioned as artificial intelligence (AI), digitisation, automation and Internet of Things (IoT) articulate the term Industry 4.0. Furthermore, the application of ICT in teaching and learning foster a new learning theory designated as Connectivism. Hence, there are needs in the formulation of an ideal and compatible classification of a social learning environment to accommodate the new learning theory, which enhances the informal learning undertaken by learners besides their formal lecture hours. Therefore, this study aims to seek factors that influenced learners' preferences toward social learning spaces. A qualitative study was adapted to investigate the learner's preferences attributes on social learning spaces at Polytechnics. An adapted questionnaire consisting of 39 items was administered to 300 Polytechnic students from three Polytechnics in Malaysia. In particular, data were analysed using exploratory factor analysis (EFA) with IBM SPSS version 22. The results from this research recommended a typology of six social learning space preferences attributes as a multidimensional construct with its two underlying dimensions: physical preferences and social preferences. The findings can help in redesigning and planning of social academic learning space in tertiary education institutions to enhance education towards 21 st Century Education.
\end{abstract}

Keywords: social learning space, informal learning, urban campus planning, 21st Century Education, learner's preferences attributes, learning environment

\footnotetext{
${ }^{2}$ Senior Lecturer at Universiti Sains Malaysia. Email: nooriati@usm.my
} 
PLANNING MALAYSIA

Journal of the Malaysia Institute of Planners (2020)

\section{INTRODUCTION}

In considering upcoming education trend disciplines, current learners and graduates shall be developed to face the challenges towards Industrial Revolution 4.0 and academic revolutions (Mohayidin et al., 2014). Imperatively, the extensive consumption of the Information and Communication Technology (ICT) and rapid developments in technologies such as artificial intelligence (AI), digitalisation, automation, big data, data sciences, robotics and Internet of Things (IoT), coining the term of Industry 4.0 (Freigang et al., 2018; Ministry of Higher Education, 2018; Puncreobutr, 2016). Therefore, the emerging technological breakthrough emphasises the urge to redesign an ideal and compatible academic learning space and has been a crucial debate topic among academician across the globe (Ibrahim, Fadzil, \& Saruwono, 2013; Nenonen, 2015; Yap, Neo, \& Neo, 2016). Thus, tertiary education is now moving ahead from boundaries looking into the requirements and compatibility of Next-Generation Learning Space whereby, merged by different types of the learning environment.

In this study, the focus will be distinguishing the impact factors that have influenced on learner's learning space preferences attributes towards social learning spaces. Pointed out in the literature, traditional learning theories named as behaviourism, cognitivism, and social constructivism occurred without technology in teaching and learning in schools (Beckers, 2016) (refer figure 1). Consequently, the application of ICT in teaching and learning produced a new learning theory, termed as Connectivism (Goldie, 2016; Marais, 2011; Siemens, 2005). According to Siemens (2005), connectivism is not only learning from peers but learning in the contacts as well, especially from social, digital or virtual networking. Hence, an active social learning space is needed. As coined by Downes (2007), connectivism consummate the needs of 21 st-century learner's skills where learners progress far away from content expenditure into critical thinking, collaboration, and content formulation.
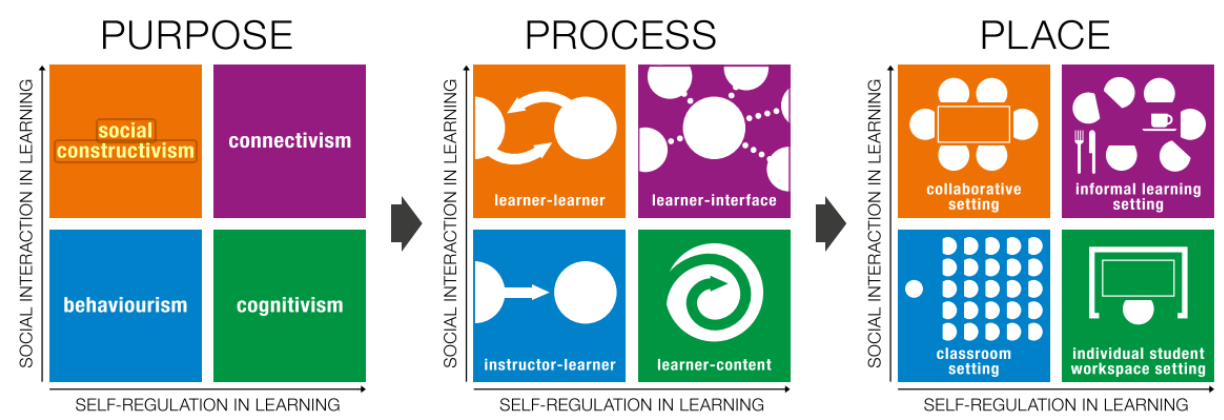

Figure 1: Purpose-process-place framework for education Source: A Learning Space Odyssey by R. Beckers (2016) 
V. Ramu, Nooriati Taib, Nor Fadzila Aziz

The Attributes of Future Social Learning Built Environments Towards 21st Century Education in Tertiary Education

\section{LITERATURE REVIEW}

As mentioned by Brown \& Lippincott (2003), at present more learning activities accorded out-of-classroom learning than ever before. The statement above emphasises the foremost part of social learning spaces in learner's daily life on urban campus. This point of view directs that it is crucial to explore the new concept of informal learning space which is synonymous to social learning space. No doubt, informal learning has been appearing at all levels (Cunningham \& Walton, 2016) and promotes and enhances student's engagement, learning experiences, self-regulated learning and collaborative learning as well (Amit Kumar, 2015; Dole et al., 2016; Wilson \& Cotgrave, 2016). Currently, students in higher education are utilising transitional spaces such as foyers, internal corridors, hallway, external corridors, gazebo, pavilion, terrace and square as their social learning space in managing their learning activities. Pointed out in the literature, the behavioural factors of students and the functional attributes of learning space are influencing the selection of social learning space (Baker, 1968). Therefore, this scenario urges the researchers and academicians around the globe to explore the importance of social learning built environments towards $21^{\text {st }}$-century education.

Imperatively, how learners utilise the social learning space and how it can be a redesign for future educational planning need to take into consideration so that can be aligned with education 4.0 (Hunter \& Cox, 2014).The recent trend of online learning results in possibilities of learning anywhere with regards to the support of wireless internet connection. The long hours of online learning will now require a conducive environment to support learner's concentration on the dependency on electronic gadgets, commonly laptops and smartphones. Cunningham \& Walton (2016) explained that social learning space as a third space and blend area where learners able to concentrate autonomously and mingle with peers. The nature of informal learning style should encourage connectivity and conversation through social activities and sometimes spontaneous acts within the environment setting itself. Boys (2010), claimed that there were "almost" no records regarding this research on this area. Therefore, research needs to be done in order to explore the usefulness and effectiveness of the new emerging learning built environment.

\section{METHOD}

Informal learning space is only significant for Post-secondary education. Postsecondary comprises Universities, Polytechnics, Kolej Komuniti, and ILP. In specific, the 4th shifts focus on the Quality Technical and Vocational Education and Training (TVET) graduates. Under the Economic Transformation Programme (ETP), Malaysia will require a 2.5 -fold increase in TVET enrolment by 2025 . Further, TVET is seen as a less attractive pathway than university education. Therefore, Malaysia needs to make sure academic and TVET 
pathways are equally valued and cultivated (Kementerian Pendidikan Malaysia, 2015). The focus population in this research is Malaysian Polytechnic students who studying in three Polytechnics: Ungku Omar Polytechnic established in 1969, Sultan Abdul Halim Mu'Adzam Shah Jitra Kedah established in 1987, and Seberang Prai Polytechnic established in 1999. In addition, several institutions in Malaysia are located in sub- urban areas where accessibility to public facilities such as parks or open space may be limited. In addressing this limitation, research needs to be executed in order to explore the learners social learning space preferences attributes. This survey research involves $(\mathrm{N}=300)$ full-time diploma students which comprise technical and non-technical academic programmes. In detail, the technical academic programme consists of diploma in Architecture, diploma in Electrical, diploma in Marine Engineering, and diploma in Mechanical Engineering. Meanwhile, the non-technical academic programme consists of diploma in commerce, diploma in Islamic Banking, diploma in accounting, and diploma in Marketing. The questionnaire that developed to acquire research data which encompasses two parts- Part A and B. Part A involves questions associated with learners' demographics. Part B of the survey related to learner's preferences on social learning space entailing of seven constructs adapted from Beckers, van der Voordt, \& Dewulf (2016); Yang, Becerik-Gerber \& Mino (2013); Kumar \& Bhatt (2015); Beckers et al., (2016); Wilson \& Cotgrave (2016); Kamis et al. (2015); Ibrahim, Fadzil \& Saruwono (2013). The students were clustered based on the semester for each department from three selected polytechnic and a consensus number of 100 students (4 semesters) were randomly selected from each polytechnic. In sum, a total of 300 students were chosen for the Exploratory Factor Analysis (EFA).

\section{INSTRUMENTATION}

Items were established to measure each dimension of learner's preferences on social learning space based on its operationalisation and existing questionnaires, as stated in table 1, respectively. In order to review the items, 3 expert reviewers were invited to review the content validity and reliability of the underlying dimension of learner's preferences towards social learning space. The three expert reviewers were from diverse disciplines in the local higher education institutions. Based on the comments given by experts, quite a few items were found ambiguous, need to rephrase, the items need to be in English and Bahasa Malaysia version, and no items were deleted. A Preliminary test was conducted to ensure the suitability, phrasing, arrangement and instruction. The sample involved in the test is excluded from the study. Finally, a full set of dual language questionnaires with a 5-point Likert-type scale, ranging from 1 (strongly disagree), 2 (disagree), 3 (Neutral), 4 (agree) to 5 (strongly agree) was administered in the pilot study. 
V. Ramu, Nooriati Taib, Nor Fadzila Aziz

The Attributes of Future Social Learning Built Environments Towards 21st Century Education in Tertiary Education

Table 1: Conceptualization and Operationalization of learner' perception

\begin{tabular}{|c|c|c|}
\hline Dimension & Conceptualization & Operationalisation \\
\hline $\begin{array}{l}\text { Interaction } \\
(5 \text { items })\end{array}$ & $\begin{array}{l}\text { Learner's involvement in collaborative- } \\
\text { learning among peers (Roskos K \& Neuman } \\
\text { SB. 2011; Yang Z, Becerik-Gerber B, Mino L, } \\
\text { 2013) }\end{array}$ & $\begin{array}{l}\text { The extent to which students are } \\
\text { involved in group learning }\end{array}$ \\
\hline $\begin{array}{l}\text { Autonomy } \\
\text { (4 items) }\end{array}$ & $\begin{array}{l}\text { Personal control in deciding what to do, } \\
\text { where, and when. (Beckers, Van der Voordt \& } \\
\text { Dewulf, 2016; Harrop \& Turpin, 2013) }\end{array}$ & $\begin{array}{l}\text { Identified the desired autonomy } \\
\text { level among students }\end{array}$ \\
\hline $\begin{array}{l}\text { Privacy } \\
\text { (5 items) }\end{array}$ & $\begin{array}{l}\text { Behavioural aspects of the learner's } \\
\text { individual preferences. } \\
\text { (T. Jessop, D. Harrop, B. Turpin, 2013) }\end{array}$ & $\begin{array}{l}\text { The dynamic process to control } \\
\text { the level of interaction which } \\
\text { varies according to individual }\end{array}$ \\
\hline $\begin{array}{l}\text { Layout } \\
\text { (4 items) }\end{array}$ & $\begin{array}{l}\text { The utilisation of the physical learning } \\
\text { environment. (Yang Z, Becerik-Gerber B, } \\
\text { Mino L, 2013, O'Rourke \& Gonzalez- } \\
\text { Metcalf, 2011) }\end{array}$ & $\begin{array}{l}\text { The degree of how the physical } \\
\text { setting facilities students in } \\
\text { learning activities }\end{array}$ \\
\hline $\begin{array}{l}\text { ICT facilities } \\
\text { (5 items) }\end{array}$ & $\begin{array}{l}\text { The usefulness of modern ICT facilities } \\
\text { supporting the new way of learning. (A. } \\
\text { Kumar, R. Bhatt, 2015; R. Beckers, 2016; } L \text {. } \\
\text { Abevsekera, P. Dawson, 2015) }\end{array}$ & $\begin{array}{l}\text { To what extent ICT facilities } \\
\text { provide an opportunity to study } \\
\text { anytime, anyhow, and anywhere. }\end{array}$ \\
\hline $\begin{array}{l}\text { Comfort } \\
\text { (12 items) }\end{array}$ & $\begin{array}{l}\text { Learners attain their learning objective with a } \\
\text { conducive learning environment. (S. Ahmad, } \\
\text { M. Shaari, R. Hashim et al., 2015; Abbas, } \\
\text { Othman \& Rahman, 2012) }\end{array}$ & $\begin{array}{l}\text { To what extents students } \\
\text { perceive comfort social learning } \\
\text { setting. }\end{array}$ \\
\hline $\begin{array}{l}\text { Aesthetic } \\
\text { (4 items) }\end{array}$ & $\begin{array}{l}\text { Attributed as design elements such as colour } \\
\text { schemes, quality floor finishing, and } \\
\text { decorative features. } \\
\text { (Fisher, 1998; L. Scannell, R. Gifford, 2017) }\end{array}$ & $\begin{array}{l}\text { The extent to which students } \\
\text { distinguish aesthetic factors } \\
\text { influencing their learning } \\
\text { activities }\end{array}$ \\
\hline
\end{tabular}

Source: Author

\section{ANALYSIS}

SPSS Version 22.0 is used to enter all the data from the questionnaire. Principal components extraction method and varimax orthogonal rotation were implemented in order to attain the uncorrelated extracted factors with the eigenvalues greater than 1.0. More concisely, standardised factor loading and Cronbach's alpha are two statistical measures used to examine the extracted factor structures of each variable. The cut-off value for standardised factor loading is .50 (Hair et al., 2014) and above whereas Cronbach's alpha is .70 and above (Peterson, 2013; Thien et al., 2014)

\section{RESULTS}

Basically, learner's preferences towards social learning space consisted of 39 items used to quantify seven dimensions, namely, (a) interaction, (b) autonomy, (c) privacy, (d) layout, (e) ICT facilities, (f) comfort, and (g) aesthetic. The Kaiser-Meyer-Olkin measure of sample adequacy index was .91. Bartlett's test of sphericity was significant. Hence, this result designates that the data were fit well for factor analysis. Based on the EFA, six orthogonal factors with eigenvalues greater than 1.0 were produced with a total of 39 items (refer table 2). Considering this, the six factors extracted signified six dimensions of the 
learner's preferences towards social learning spaces namely (a) collaborative learning space, (b) self-regulated learning space, (c) private space, (d) ICT provision conducive space, (e) adequate amenities space, and (f) appealing design and layout space. Based on table 2, the loading factor for each item fluctuated from .81 to .55 , which above the cut-off value of .50 (Hair et al., 2014). Meanwhile, those items loaded below the cut-off value of .50 were excluded namely item 12 , item 18 , item 32 , and item 35 . In addressing this limitation, item 15, item 16, and item 17 were forced to be deleted due to the Cronbach's Alpha .224 below the permissible level after running the reliability analysis.

As a result, the first factor encompassed items 19, 20, 21, 22, 23,30, 33, and 34. In other words, those items principally designated the ICT provision conducive learning space. Subsequently, the second factor described adequate amenities space comprising five items, namely, items 24, 25, 26, 27 and 28. The third factor represented appealing design and layout space, which comprised items $36,37,38,39$ and 31 . Factor fourth explained about the privacy which encompassed 5 items, listed as items 9,10,11,13 and 14. The fifth factor detailed about the self-regulated learning space covered items 5,6,7, and 8. Finally, the sixth factor explained collaborative learning space which indicated in items no 1 , 2,3 and 4.

\section{DISCUSSION AND CONCLUSION}

The finding reveals that the learner's preferences towards social learning built environments are a multidimensional construct consist of six fundamental dimensions: (a) collaborative learning space, (b) self-regulated learning space, (c) privacy learning space, (d) ICT provision conducive learning space, (e) adequate amenities learning space, and (f) appealing design and layout learning space. Imperatively, one novel feature of this research is the learner's utilisation and preferences on social learning built environments towards $21^{\text {st }}$ education and the attributes as well. In relation to this, those six dimensions are perceived as an explicit social learning space attributes which need to take into consideration during the early stage in the urban campus ecosystem design.

Table 2: Analysis of Exploratory Factor Analysis

\begin{tabular}{|c|c|c|c|c|}
\hline Items & Loading & Item description & Label & $\boldsymbol{\alpha}$ \\
\hline 1 & .681 & $\begin{array}{l}\text { My favourite locations whenever I am free to meet } \\
\text { my friend regarding studies. }\end{array}$ & \multirow{4}{*}{$\begin{array}{l}\text { Collaborative } \\
\text { learning built } \\
\text { environments }\end{array}$} & \multirow{4}{*}{.791} \\
\hline 2 & .763 & Place where easy to meet my friends. & & \\
\hline 3 & .751 & Suitable space to study with my friend. & & \\
\hline 4 & .642 & Preferred space for group studies with mates. & & \\
\hline 5 & .551 & $\begin{array}{l}\text { A place that I can use for a student's project } \\
\text { presentation. }\end{array}$ & \multirow{4}{*}{$\begin{array}{l}\text { Self-regulated } \\
\text { learning built } \\
\text { environments }\end{array}$} & \multirow{4}{*}{.732} \\
\hline 6 & .674 & Where I can have my power nap. & & \\
\hline 7 & .744 & Provide a homely environment. & & \\
\hline 8 & .674 & Where I can have personal discussion with lectures. & & \\
\hline
\end{tabular}


V. Ramu, Nooriati Taib, Nor Fadzila Aziz

The Attributes of Future Social Learning Built Environments Towards 21st Century Education in Tertiary Education

\begin{tabular}{|c|c|c|c|c|}
\hline 9 & .759 & Place where I can get more personal. & \multirow{5}{*}{$\begin{array}{l}\text { Privacy learning } \\
\text { built environments }\end{array}$} & \multirow[t]{5}{*}{.856} \\
\hline 10 & .546 & A place where can provide more peaceful mind. & & \\
\hline 11 & .586 & Privacy spot which no disturbance from others. & & \\
\hline 13 & .572 & Place with noise- free area. & & \\
\hline 14 & .807 & Place where I can get more privacy. & & \\
\hline 19 & .718 & Have good access to the wireless network & \multirow{8}{*}{$\begin{array}{l}\text { ICT provision } \\
\text { conducive built } \\
\text { environments }\end{array}$} & \multirow{8}{*}{.913} \\
\hline 20 & .813 & 3 pin electrical power supply is available. & & \\
\hline 21 & .772 & Computer is available for quick online access. & & \\
\hline 22 & .809 & Printing services are available. & & \\
\hline 23 & .551 & $\begin{array}{l}\text { Student centre that opens } 24 \text { hours, which provide } \\
\text { facilities such as space for group and individual } \\
\text { studies, printing services, cafe, and computer lab. }\end{array}$ & & \\
\hline 30 & .504 & $\begin{array}{l}\text { A place that provides a comfortable and appropriate } \\
\text { chair and table. }\end{array}$ & & \\
\hline 33 & .511 & Very good shading on the study area. & & \\
\hline 34 & .521 & Good ventilation. & & \\
\hline 24 & .606 & $\begin{array}{l}\text { Ergonomically/comfort moveable tables and chairs } \\
\text { for the students }\end{array}$ & \multirow{5}{*}{$\begin{array}{l}\text { Adequate } \\
\text { amenities built } \\
\text { environments }\end{array}$} & \multirow{5}{*}{.854} \\
\hline 25 & .711 & $\begin{array}{l}\text { Provide sufficient water dispenser and vending } \\
\text { machine. }\end{array}$ & & \\
\hline 26 & .762 & Provide food and beverage take-away service. & & \\
\hline 27 & .528 & A place that can be used for an exhibition venue. & & \\
\hline 28 & .579 & Have access to food and drink. & & \\
\hline 31 & .556 & Prefer to have a natural environment. & \multirow{5}{*}{$\begin{array}{l}\text { Appealing design } \\
\text { and layout built } \\
\text { environments }\end{array}$} & \multirow{5}{*}{.873} \\
\hline 36 & .769 & $\begin{array}{l}\text { Very attractive colour scheme and decorative space } \\
\text { design. }\end{array}$ & & \\
\hline 37 & .780 & Nice landscape and plants. & & \\
\hline 38 & .795 & Good floor finishing and wall decorative. & & \\
\hline 39 & .769 & Good lighting is required. & & \\
\hline
\end{tabular}

As defined by Cleveland \& Fisher (2014), informal learning setting is a group learning space, and it is revealed based on research findings. The first social learning space attributes itemised as collaborative learning builtenvironments. This construct explained learners' preferences towards collaboration and interpersonal interaction with the peer, course mates, and even with lecturers (Harrop \& Turpin, 2013). In fact, this location can be learners' favourite location, and this is supported by a very good factor loading which is above 60 (Hair et al., 2014). Evidence shows that learners learn more outside the classroom compared inside the classroom (Maheran, Fadzidah, Nur Fadhilah \& Farha, 2017; Yang, Becerik-Gerber, \& Mino, 2013) and conversation is the critical factor for "significant learning can occur.

Meanwhile, the self-regulated/directed built environments attribute associated with the individual pod which emphasises on autonomy and own territory with self-rule. In short, autonomy refers to in deciding what to do, where and when (Beckers, 2016). Interestingly, finding reveals that learners requested to have a homely environment which is a private space where they can perform personal meetings with the lecturer, and also to have a short power nap (item no 6 and 7 with a factor loading of .64 and .74). For instance, students prefer to have 
an isolated and silent spot where they don't want to be focused on by others and listen to their own music. The third attributes fixated on privacy, and sometimes the preference for privacy and self-regulated go hand in hand. In fact, those learning settings can be found mostly located in the library (Cunningham \& Walton, 2016). Basically, this space is a fully enclosed space which needs concentration. This informal learning setting is providing less disturbance and less noise from the surrounding. Thus, the entire university campus would be better to be planned not in an urban area but more too semi-urban. Whereby, the learners can concentrate on their studies. In sum, those three attributes (a) collaborative learning space, (b) Self-regulated learning space, and (c) privacy learning space is driven under social dimension (Beckers, 2016; Beckers, Van Der Voordt, et al., 2016; Harrop \& Turpin, 2013).

Pointed out in the literature, new modern technology has influenced the learning space from traditional classrooms to various and diverse learning settings (Yun et al., 2016). In addressing this issue, ICT provision conducive space is very much paramount in $21^{\text {st }}$-century universities campus planning and design. Therefore, during the preliminary university campus design, site investigation plays an important role. The planner needs to know the capacity of internet coverage. Therefore, the entire campus has to situate at an urban area in which the coverage is robust (Walton \& Matthews, 2018). ICT provision is referring to efficient wireless internet coverage in urban campus, adequate 3 pin power supply, twenty-four-seven student centre and quick online access which is associated with item no 19-23 with factor loading very high .8 and with Cronbach's Alpha .91 which is very reliable.

Prior to research, learners prefer to have a sufficient and adequate water dispenser and vending machine around social learning space, take-away service, fast food like KFC on campus, proper presentation space, and comfortable tables and chairs (item no 25-28 with Cronbach's Alpha .85). In fact, students don't prefer to sit on the precast concrete bench, which is not comfortable and yet provided everywhere on campus. In addition, social learning space preferences are attributed to the appealing design and layout space. As mentioned in the literature, an attractive and well-design layout can promote learning (Beckers, Van Der Voordt, et al., 2016). The millennium learners demanded to have an attractive soft and hard landscape rather than just a "wakaf ", good colour scheme and decorative space design, suitable floor finishes and adequate natural and artificial lighting. Imperatively, statistical analysis of this paper shows that items that load under appealing design layout construct obtained factor loading as .70 and above. As explored all the constructs above, in sum, illustrated in figure 2. It was demonstrated how those social learning space preferences attributes were integrated within a learning environment which domain with three components namely (a) space (architecture), (b) pedagogy (education), and (c) Technology 
V. Ramu, Nooriati Taib, Nor Fadzila Aziz

The Attributes of Future Social Learning Built Environments Towards 21st Century Education in Tertiary Education

(Computer science) and familiarised as "The Pedagogy-Space-Technology" (PST) (Ng, 2015).

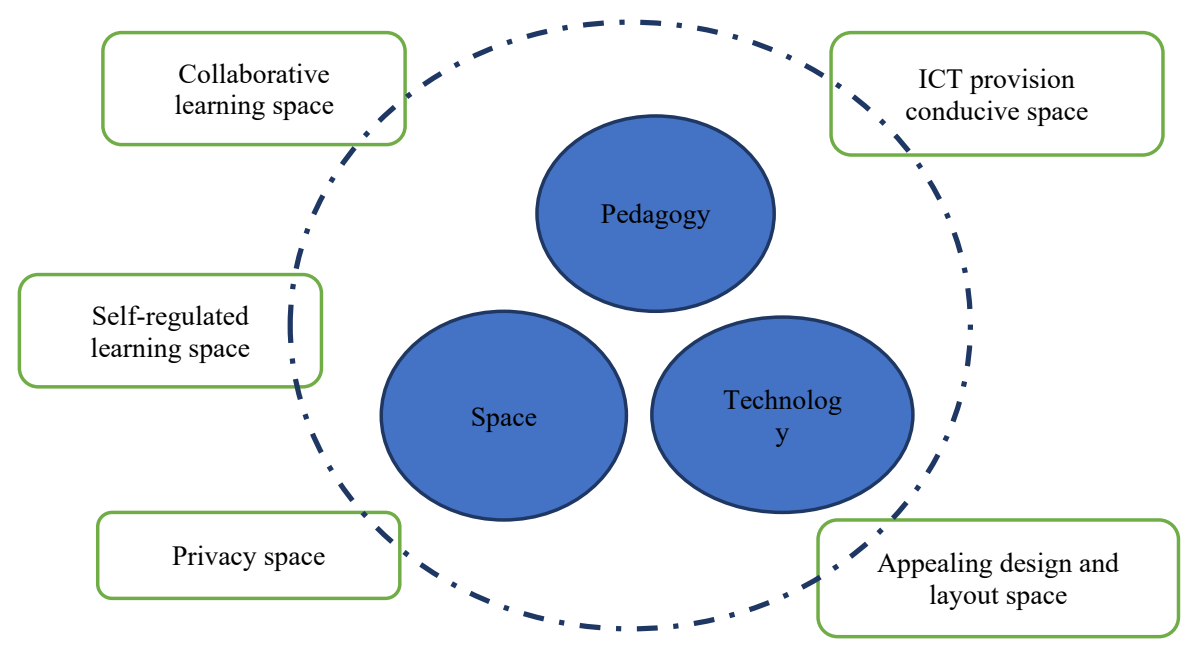

Figure 2: Social learning Environment preferences attributes. Source: Author

Therefore, as mentioned by Maheran et al., (2017), appropriate design of social learning space in higher education institutions promotes and contributes to the learner's education performance and enhances improved learning outcomes. As stated by Walton \& Matthews (2018), before deciding on the strategic approach, it would be wise to evaluate what the surrounding city or urban area provides in terms of the spectrum of informal learning space. For instance, many institutions in Malaysia are situated in the sub- urban areas where informal learning relies mostly on the facilities offered by the institutions alone. In fact, those campuses in the cities or urban areas will have better accessibility of facilities, particularly the ICT provision which is one of the major learning space attributes from this study. At present, universities still predominate by the conventional instructional method without taking into account the affordance of social learning-built environments (Ibrahim et al., 2013). Therefore, in order to bridge the gap, it is vital for a partnership between university stakeholders to take into account those five social learning space attributes during the urban campus planning. The main reason here is, to form a joined-up plan and approach to deliberate the suitability of social learning built-environments in $21^{\text {st }}$ century education urban campus planning. 
PLANNING MALAYSIA

Journal of the Malaysia Institute of Planners (2020)

\section{ACKNOWLEDGEMENT}

This research was funded by MOHE and USM under Fundamental Research Grant Scheme (FRGS) 1001/PPBGN/6711669.

\section{REFERENCES}

Amit kumar. (2015). A Study of Using Informal Learning Spaces at Indian Institute of Technology, Delhi. Digital Commons@University of Nebraska - Lincoln, August.

Baker, R. (1968). Ecological Psychology: Concept and Methods for Studying the environment of human Behavior. STANFORD UNIVERSITY PRESS, STANFORD, CALIFORNIA.

Beckers, R. (2016). A Learning Space Odyssey. Brighton: University of Brighton Press. ISBN 978-90-365-4105-3

Beckers, R., Van Der Voordt, T., \& Dewulf, G. (2016). Learning space preferences of higher education students. Building and Environment, 104, 243-252. https://doi.org/10.1016/j.buildenv.2016.05.013

Boys, J. (2010). Towards Creative Learning Spaces: Re-thinking the Architecture of PostCompulsory Education. Routledge, Oxford.

Brown, M. B., \& Lippincott, J. K. (2003). Learning Spaces : More than Meets the Eye. EDUCAUSE QUARTERLY, 1, 14-16.

Cleveland, B., \& Fisher, K. (2014). The evaluation of physical learning environments : A critical review of the literature. Learning Environ Res, 17(April), 1-28. https://doi.org/10.1007/s10984-013-9149-3

Cunningham, M., \& Walton, G. (2016). Informal learning spaces (ILS) in university libraries and their campuses. New Library World, 117(1/2), 49-62. https://doi.org/10.1108/NLW-04-2015-0031

Dole, S., Bloom, L., Kowalske, K., Dole, S., Bloom, L., Kowalske, K., \& Carolina, W. (2016). Transforming Pedagogy: Changing Perspectives from Teacher-Centered to Learner-Centered. Interdisciplinary Journal of Problem-Based Learning Volume, 10(1).

Downes, S. (2007). Learning networks in practice. Emerging Technologies for Learning, 2, 19-27. https://doi.org/10.1039/B910216G

Freigang, S., Schlenker, L., \& Köhler, T. (2018). A conceptual framework for designing smart learning environments. Smart Learning Environments, 8.

Goldie, J. G. S. (2016). Connectivism : A knowledge learning theory for the digital age ? Medical Teacher, 38(No. 10), 1064-1069. https://doi.org/10.3109/0142159X.2016.1173661

Hair, J. F., Black, W. c, Babin, B. J., \& Anderson, R. E. (2014). Multivariate Data Analysis Seventh Edition.

Harrop, D., \& Turpin, B. (2013). A Study Exploring Learners' Informal Learning Space Behaviors, Attitudes, and Preferences A Study Exploring Learners' Informal Learning. New Review of Academic Librarianship. https://doi.org/10.1080/13614533.2013.740961

Hunter, J., \& Cox, A. (2014). Learning over tea! Studying in informal learning spaces. New Library World, 115(1/2), 34-50. https://doi.org/10.1108/NLW-08-20130063 
V. Ramu, Nooriati Taib, Nor Fadzila Aziz

The Attributes of Future Social Learning Built Environments Towards 21st Century Education in Tertiary Education

Ibrahim, N., Fadzil, N. H., \& Saruwono, M. (2013). Learning Outside Classrooms on Campus Ground: Malaysia. Asian Journal of Environment-Behaviour Studies, 4(13), 97-110.

Kamis, M., Muhamad, M., Junoh, A. M., Asmuni, A., \& Idris, K. (2015). Informal Learning in Malaysia. May.

Kumar, A., \& Bhatt, R. K. (2015). A Study of Using Informal Learning Spaces at Indian Institute of Technology, Delhi. Library Philosophy and Practice (e-Journal). http://digitalcommons.unl.edu/libphilprac

Maheran, Y., Fadzidah, A., Nur Fadhilah, R., \& Farha, S. (2017). A Review of Criteria for Outdoor Classroom in Selected Tertiary Educational Institutions in Kuala Lumpur. IOP Conference Series: Materials Science and Engineering, 291(1). https://doi.org/10.1088/1757-899X/291/1/012014

Marais, N. (2011). Connectivism as Learning Theory: The Force behind Changed Teaching Practice in Higher Education. Education, Knowledge \& Economy: A Journal for Education and Social Enterprise, V4(N3), p173-182.

Ministry of Higher Education, M. (2018). Framing Malaysian Higher Education 4.0. Department of Higher Education Malaysia.

Mohayidin, M. G., Suandi, T., Mustapha, G., Adam, A., Man, N. A., Konting, M. M., \& Abdullah, S. N. (2014). Implementation of Outcome-Based Education in Universiti Putra Malaysia: A Focus on Students' Learning Outcomes. International Education Studies, 1(4). https://doi.org/10.5539/ies.v1n4p147

Nenonen, E. B. Y. (2015). How to CO-CRATE campus ?

Peterson, R. A. (2013). A Meta-analysis of Alpha Cronbach’'s Coefficient. 21(2), 381391.

Puncreobutr, V. (2016). Education 4.0: New Challenge of Learning. St. Theresa Journal of Humanities and Social Sciences, 2(2), 92-97.

Siemens, G. (2005). Connectivism: A Learning Theory for the Digital Age. http://connectivism.ca

Thien, L. M., Abd Razak, N., \& Ramayah, T. (2014). Validating Teacher Commitment Scale Using a Malaysian Sample. SAGE Open, 4(2). https://doi.org/10.1177/2158244014536744

Walton, G., \& Matthews, G. (2018). Exploring Informal Learning Space in the University. Routledge.

Wilson, H. K., \& Cotgrave, A. (2016). Factors that influence students' satisfaction with their physical learning environments. Structural Survey, 34(3), 256-275. https://doi.org/10.1108/SS-01-2016-0004

Yang, Z., Becerik-Gerber, B., \& Mino, L. (2013). A study on student perceptions of higher education classrooms: Impact of classroom attributes on student satisfaction and performance. Building and Environment, 70, 171-188. https://doi.org/10.1016/j.buildenv.2013.08.030

Yap, W. L., Neo, M., \& Neo, T. K. (2016). The impact of the role of teacher and balance of power in transforming conventional teaching to learner-centered teaching in Malaysian institution of higher education. Pertanika Journal of Social Sciences and Humanities, 24(4), 1849-1868.

Yun, Z., Anan, L., Huiping, S., Lan, L., \& Fengkuang, C. (2016). The design reserach of future informal learning space constructing the "smart space" of Beijing Normal 
University Library. 19th International Conference on Knowledge-Based and Intelligent Information \& Engineering Systems, May 2015. https://doi.org/10.1007/978-3-319-19875-0

Received: January 2020. Accepted: $20^{\text {th }}$ May 2020 